crept up to the great man and touched him on the arm - GBS looked round furiously, and Pascal confessed, 'We've run out of film.'

'Run out of what?' roared GBS, who was, I imagine, fairly ignorant of such technical necessities.

It was explained to him that he must stop, to allow the cameras to reload, and then go on. The delay threw him completely. He lost his train of thought, he fumbled, and mumbled and dried up like any novice actor. I was fascinated to see this happen to a self-possessed man of such renowned intelligence. It took several reloads of the camera for him to finish what he wanted to say.

Afterwards, Pascal asked him if he would read through the last scene between Major Barbara and Cusins, and help us to interpret it. Wendy Hiller and I sat on either side of Shaw while he silently read through the long scene. There was a pause. Then he said, almost to himself, and with a strong Irish brogue: 'Ah, what a terrible scene,' and again, 'Ah, what a terrible scene.' It was exactly what we had thought. But there were no further words of wisdom forthcoming from the great man, I think because by then he was thoroughly exhausted.

\title{
Filming Caesar and Cleopatra
}

\author{
MARJORIE DEANS
}

From Marjorie Deans, Meeting at the Sphinx: Gabriel Pascal's Production of Bernard Shaw's Caesar and Cleopatra (London: Macdonald, [1946]) p. 28. The shooting of Caesar and Cleopatra, begun in June 1944 and completed in September of the following year, was carried out at Denham Studios in London and on location in Egypt.

When Bernard Shaw came to Denham to watch the filming of the meeting between Caesar and Cleopatra on the paws of the Sphinx, he stood for a long time in silence, gazing up at the huge crouching image against its background of starry sky; and his expression, though always critical, reflected also the realisation of a fifty-year-old dream.

'What scope! What limitless possibilities!' he said afterwards. 'When I look back on my work as a young man with my colleagues in the theatre, it seems to me we were like children playing with wretched makeshift toys. Here you have the whole world to play with!' 